\title{
Evaluation of Knowledge of Oxygen Therapy and Reading of Flowmeter among the Health Workers in the Pediatric Unit of the Hospital Universitario San Ignacio, Bogotá, Colombia
}

\section{Evaluación de conocimientos sobre oxigenoterapia y lectura del flujómetro en el personal de salud de pediatría del Hospital Universitario San Ignacio, Bogotá, Colombia}

Date received: 21/11/2017 | Date accepted: 04/04/2018

\author{
Elly Morros-GonzÁlez \\ Pontificia Universidad Javeriana, Colombia \\ Diana Estrada Cano ${ }^{b}$ \\ Pontificia Universidad Javeriana, Colombia \\ Marcela Murillo Galvis ${ }^{c}$ \\ Pontificia Universidad Javeriana, Colombia \\ José CARlos Montes ${ }^{\mathrm{d}}$ \\ Pontificia Universidad Javeriana, Colombia \\ Nelcy Rodríguez Malagón ${ }^{\mathrm{e}}$ \\ Pontificia Universidad Javeriana, Colombia \\ Claudia Marcela Granados ${ }^{\mathrm{f}}$ \\ Pontificia Universidad Javeriana, Colombia \\ a MD, Pontificia Universidad Javeriana, Bogotá, \\ Colombia. \\ b Pediatrician. Professor in the Department \\ of Pediatrics at Hospital Universitario San \\ Ignacio-Pontificia Universidad Javeriana, Bogotá, \\ Colombia. \\ c Pediatrician. Professor in the Department \\ of Pediatrics at Hospital Universitario San \\ Ignacio-Pontificia Universidad Javeriana, Bogotá, \\ Colombia. \\ d Fourth semester student of Medicine, Pontificia \\ Universidad Javeriana, Bogotá, Colombia. \\ e Biostatistician. Director of the Department of \\ Clinical Epidemiology and Biostatistics, Pontificia \\ Universidad Javeriana, Bogotá, Colombia. \\ f Pediatrician, clinical epidemiologist. Professor in \\ the Departament of Clinical Epidemiology and \\ Biostatistics, Pontificia Universidad Javeriana, \\ Bogotá, Colombia.
}

How to cite: Morros-González E, Estrada Cano D, Murillo Galvis M, Montes JC, Rodríguez Malagón N, Granados CM. Evaluation of Knowledge of Oxygen Therapy and Reading of Flowmeter among the Sanitary Personnel in the Pediatric Unit of the Hospital Universitario San Ignacio, Bogotá, Colombia. Univ. Med. 2018;59(3). doi: https:// doi.org/10.11144/Javeriana.umed59-3.oxig

\begin{abstract}
Introduction: Supplemental oxygen is considered a pharmaceutical drug; therefore, it can produce adverse effects. Lack of consensus regarding the reading of oxygen flowmeters and the peripheral oxygen saturation $\left(\mathrm{SpO}_{2}\right)$ goals can influence clinical and paraclinical decisions and hospital stay length. Objective: To assess knowledge on oxygen therapy, adverse effects, $\mathrm{SpO}_{2}$ goals and reading of oxygen flowmeters among personnel in the Pediatric Unit at Hospital Universitario San Ignacio, Bogotá, Colombia. Methodology: Cross-sectional study derived from convenience sampling through a self-applied survey between December 2016 and January 2017. The poll evaluated topics on supplemental oxygen therapy fundamentals and adverse effects, $\mathrm{SpO}_{2}$ goals and flowmeter readings through flowmeters photographs indicating a specific fraction of inspired oxygen $\left(\mathrm{FiO}_{2}\right)$. Results: The response rate was $77 \%$ from 259 subjects. $22 \%$ considered that the oxygen saturation either increases or remains the same during sleep periods in children. $78 \%$ of participants knew at least one complication associated to prolonged oxygen therapy and $67 \%$ due to supplemental oxygen concentration greater than required. In neonatal population, $10 \%$ considered oxygen saturation goals equal to or greater than $96 \%$. In the flowmeter's reading evaluation, incorrect answers ranged from 9 to $19 \%$. Conclusion: It is imperative to reinforce updated concepts on oxygen therapy, with
\end{abstract}


emphasis in $\mathrm{SpO}_{2}$ goals, adverse effects and appropriate flowmeter's readings through periodic educational campaigns.

Keywords

oxygen inhalation therapy; oximetry; flowmeters; pediatrics; Colombia; $\mathrm{SpO} 2 ; \mathrm{O} 2$.

\section{RESUMEN}

Introducción: el oxígeno $\left(\mathrm{O}_{2}\right)$ es un medicamento que puede generar efectos adversos. Discrepancias en la lectura del flujómetro y metas de saturación de oxígeno $\left(\mathrm{SpO}_{2}\right)$ pueden repercutir en la toma de decisiones clínicas, paraclínicas y estancia hospitalaria de pacientes pediátricos. Objetivo: evaluar los conocimientos sobre $\mathrm{SpO} 2$, efectos adversos del $\mathrm{O}_{2}$ y lectura del flujómetro en el personal de salud del Departamento de Pediatría del Hospital Universitario San Ignacio, Bogotá, Colombia. Métodos: estudio transversal mediante encuesta autodiligenciada en una muestra por conveniencia durante diciembre de 2016 y enero de 2017. Evaluación de conocimientos sobre oxigenoterapia, $\mathrm{SpO}_{2}$, efectos adversos y lectura del flujómetro mediante fotografías de flujómetros del hospital con diferente fracción inspirada de oxígeno $\left(\mathrm{FiO}_{2}\right)$. Resultados: de 259 personas, el 77\% respondió la encuesta. El 22\% de los participantes respondió que la $\mathrm{SpO} 2$ aumenta o se mantiene igual cuando el niño duerme; el 78\% sabía de complicaciones del uso prolongado de $\mathrm{O}_{2}$, y el $67 \%$, las relacionadas con la administración de una $\mathrm{FiO}_{2}$ mayor a la necesaria. Con relación a la población neonatal, el 10\% consideró que se deben buscar metas de $\mathrm{SpO}_{2}$ iguales o superiores al 96\%; entre el 9\% y el 19\% de las lecturas en las diferentes fotografías de flujómetros fueron respuestas incorrectas. Discusión: es necesario reforzar conceptos actualizados sobre oxigenoterapia, con énfasis en metas de saturación, efectos adversos y lectura de flujómetro mediante campañas educativas periódicas.

Palabras clave

oxigenoterapia; oximetría; altura; niños; recién nacidos; $\mathrm{SpO} 2$; $\mathrm{O} 2$.

\section{Introduction}

The individualized prescription of supplemental oxygen $\left(\mathrm{O}_{2}\right)$ is of utmost importance $(1,2)$; for this reason, it is essential to dose it in an adequate way taking into account its adverse effects. In addition, in the city of Bogotá, normal values of oxygen saturation $\left(\mathrm{SpO}_{2}\right)$ at 2,640 meters above sea level should be considered (3).

The flowmeter is an instrument that regulates the liters of $\mathrm{O}_{2}$ supplied per minute. The most used in the hospital setting is the cylindrical one, which, with a graduated scale, contains a sphere inside, whose center is aligned with the scale and allows knowing the liters of $\mathrm{O}_{2}$ administered per minute $(4,5)$. The supplemental $\mathrm{O}_{2}$ aims to treat hypoxemia, defined as levels below the normal $\mathrm{O}_{2}$ arterial tension. $\mathrm{O}_{2}$ is necessary to maintain aerobic metabolism in the mitochondria; in addition, it is used to reduce both respiratory and cardiac work. Therefore, in children it is part of the management established for conditions such as prematurity, pneumonia, asthma, meningitis, sepsis, heart failure, anemia, trauma, cardiac arrest, among others $(6,7,8)$.

A low $\mathrm{O}_{2}$ supply during prolonged periods can produce chronic hypoxemia, which has been related to pulmonary hypertension, alterations in neurodevelopment and alterations in growth, especially in children with chronic obstructive pulmonary disease. On the other hand, prolonged use of $\mathrm{O}_{2}$ increases the $\mathrm{O}_{2}$ free radicals, inactivates the pulmonary surfactant and generates absorption atelectasis $(9,10)$, resulting in diseases such as retinopathy of prematurity and bronchopulmonary dysplasia (BPD) in newborns and in premature babies $(6,7)$. In the same way, during the hospital stay, the use of supplemental $\mathrm{O}_{2}$ in children when it is not indicated may prolong the hospitalization and increase the costs for the health system (11).

Additionally, for prescribing $\mathrm{O}_{2}$ it should be considered that $\mathrm{SpO}_{2}$ goals vary according to age, history of prematurity, altitude above sea level (3) and waking state, sleep or crying of the patient (12). Studies such as the Therapeutic Oxygen Supplementation for the Prevention of Prethreshold Retinopathy of Prematurity (STOP-ROP) and the Benefits of Oxygen Saturation Targeting (BOOST) $(13,14)$ have tried to elucidate the $\mathrm{SpO}_{2}$ goal in the preterm neonatal population; it has been recommended to achieve $\mathrm{SpO}_{2}$ goals between $88 \%$ and $95 \%$ or a partial pressure of oxygen between 50 and 70 $\mathrm{mmHg}(1,15)$, with the lowest possible fraction of inspired oxygen $\left(\mathrm{FiO}_{2}\right)$ that guarantees this $\mathrm{SpO}_{2}$ goal, since there are no findings that prove that achieving higher saturations additionally 
avoids complications due to prolonged use of supplemental $\mathrm{O}_{2}$.

During the clinical practice in the Department of Pediatrics of the Hospital Universitario San Ignacio (HUSI), the important influence of the oral tradition on the acquisition of knowledge about oxygen therapy was evidenced; in addition, there was a discrepancy in the reading of the flowmeter within the health personnel who administered the $\mathrm{O}_{2}$, which entails the possibility of systematic errors in the administration of $\mathrm{O}_{2}$ when compared to the prescription of $\mathrm{O}_{2}$ recorded in the medical history. Likewise, it was evidenced that the chronogram of review subjects in Pediatrics for undergraduate and postgraduate medical studies and for the nursing team does not usually include a specific space on oxygen therapy training. With this study we want to highlight that the changes in the in-hospital $\mathrm{O}_{2}$ requirement, ideally due to the patient's condition or erroneously due to an inadequate interpretation of the flowmeter by the health personnel who administer the $\mathrm{O}_{2}$, allow the clinical and paraclinical decision making; in addition, they become a support criterion for discharge or permanence in the hospital, with an impact on health costs.

The administration of supplemental $\mathrm{O}_{2}$ when it is not indicated-for example, by incorrect knowledge about saturation goals for a certain age in the pediatric population-may generate a greater risk of adverse effects or discomfort in children according to the $\mathrm{O}_{2}$ supply devices used; additionally, its prescription for home administration requires that family members invest time in administrative procedures, in addition to the waiting time for the necessary implements to arrive at home, such as $\mathrm{O}_{2}$ tanks and an $\mathrm{O}_{2}$ concentrator.

The objective of the present study was to evaluate the correct reading of the flowmeter and the knowledge about oxygen therapy in general, including the $\mathrm{SpO}_{2}$ variation and the goals according to age and adverse effects in the health personnel of the Department of Pediatrics of HUSI (Bogotá, Colombia).

\section{Methodology}

Cross-sectional study through a selfadministered survey, carried out during 7 nonconsecutive days in the personnel that worked or practiced during the day shift in the Department of Pediatrics of HUSI between December 2016 and January 2017, including the hospitalization area, emergency room, newborn and intensive care units. It was a convenience sample with voluntary participation.

The instrument included the following demographic data: age, years of clinical experience and occupation. The first section consists of 10 questions on generalities of oxygen therapy (consider whether supplemental $\mathrm{O}_{2}$ is a drug, consider whether the dose and the goal are prescribed in the medical history, $\mathrm{SpO}_{2}$ goals expected by age at the altitude above sea level in Bogotá, $\mathrm{SpO}_{2}$ variation according to wakefulness vs. sleep, adverse effects due to prolonged use of $\mathrm{O}_{2}$ and the use of higher amounts of $\mathrm{O}_{2}$ and mentioning which, equivalence between constant $\mathrm{FiO}_{2}$ and liters administered). The second section, with 7 photographs of hospital flowmeters, including a photograph called "confounding", which showed a flowmeter sphere that did not show a specific measurement of liters of $\mathrm{O}_{2}$ per minute; the purpose was to evaluate the identification of the inadequate location of the flowmeter sphere (see Annex 1).

The study complies with the ethical principles for medical research in humans established by the Declaration of Helsinki of the World Medical Association, and was approved by the Committee of Research and Ethics of the Pontificia Universidad Javeriana on 16 November 2016. All participants signed an informed consent. 200 surveys were completed. Table 1 shows the characteristics of the surveyed population. 
Table 1

General Characteristics of the Population

\begin{tabular}{|c|c|c|}
\hline Characteristics & n (\%) & \\
\hline \multicolumn{3}{|l|}{ Position } \\
\hline Medical student & $88(44.0)$ & \multirow{5}{*}{$\mathrm{n}=200$} \\
\hline Nursing team (heads and assistants) & $55(26.5)$ & \\
\hline Pediatrics or Family Medicine Resident & $27(13.5)$ & \\
\hline $\begin{array}{l}\text { Pediatrician (includes neonatologists; } n=4 \text { ) } \\
\text { Pediatrician (includes neonatologists, } n=4 \text { ) }\end{array}$ & $22(11.0)$ & \\
\hline $\begin{array}{l}\text { Respiratory therapy team (physiatrist and } \\
\text { respiratory therapist) }\end{array}$ & $10(5.0)$ & \\
\hline \multicolumn{3}{|l|}{ Age in years } \\
\hline $20-30$ & $131(66.8)$ & \multirow{3}{*}{$\mathrm{n}=196^{*}$} \\
\hline $31-40$ & $45(23.0)$ & \\
\hline$>40$ & $20(10.2)$ & \\
\hline \multicolumn{3}{|c|}{ Years of professional practice } \\
\hline $0.5-5$ & $28(30.1)$ & \multirow{5}{*}{$\mathrm{n}=93^{* *}$} \\
\hline 6-10 & $27(29.0)$ & \\
\hline $11-15$ & $18(19.4)$ & \\
\hline $16-20$ & $15(16.1)$ & \\
\hline$>20$ & $5(5.4)$ & \\
\hline
\end{tabular}

*There are fewer answers presented because of incomplete filling of the survey.

**There are fewer answers presented because of non-applicability for medical student and for incomplete filling of the survey.

The instructions for use of the flowmeter were taken from the instruction manual of Pacific Hospital Supply Co., Ltd (PAHSCO), supplier of the flowmeters used at HUSI, adjusting the flow by aligning the center of the floating sphere with the graduation line of the cylindrical tube.

The answers were coded and included in a data base made in Microsoft Excel Office 2013, and Stata 2015 was used for data processing and calculation of frequencies and proportions. A descriptive analysis was carried out according to the profession of the personnel in the question that evaluated $\mathrm{SpO}_{2}$ goals in neonates and in the readings of the flowmeters.

\section{Results}

The response rate was $77 \%$ (200 volunteer participants from 259 potential participants). The majority of the surveyed population corresponded to medical students; $67 \%$ of the participants were between 20 and 30 years old, and $70 \%$ of those who were not students had 6 years or more of professional practice. Table 1 provides more information about the general characteristics of the participants.
99\% of the participants considered that $\mathrm{O}_{2}$ is a drug, $91 \%$ indicated that $\mathrm{O}_{2}$ is often prescribed with its dose in the medical history, and $84 \%$ answered that the $\mathrm{SpO}_{2}$ goal is regularly prescribed in the medical history. $22 \%$ of respondents answered that $\mathrm{SpO}_{2}$ increases or remains the same when the child is asleep (Table 2). Regarding adverse effects due to oxygen therapy, $78 \%$ answered that they knew at least one complication due to prolonged use of oxygen and $67 \%$ knew at least one complication due to the use of oxygen amounts greater than necessary. The most frequently mentioned complications are shown in Table 3.

\section{Table 2}

Answers on Basic Knowledge of Oxygen Therapy and Readings of Flowmeters

\begin{tabular}{|c|c|c|}
\hline Knowledge & \multicolumn{2}{|c|}{ Answer n (\%) } \\
\hline Considers that oxygen is a drug $(\mathrm{n}=200)$ & \multicolumn{2}{|r|}{$198(99,0)$} \\
\hline $\begin{array}{l}\text { Considers that oxygen is often prescribed } \\
\text { with its dose in the medical history } \\
\text { ( } \mathrm{n}=199)\end{array}$ & \multicolumn{2}{|r|}{$181(91,0)$} \\
\hline $\begin{array}{l}\text { Considers that oxygen is often prescribed } \\
\text { with a goal in the medical history }(n=197)\end{array}$ & \multicolumn{2}{|r|}{$165(83.8)$} \\
\hline $\begin{array}{l}\text { Oxygen saturation } \\
\text { is asleep }(\mathrm{n}=198)\end{array}$ & Decreases $\bullet$ & $155(78.3)$ \\
\hline \multirow{3}{*}{$\begin{array}{l}\text { Equivalent in inspiratory fraction of } \\
\text { oxygen }\left(\mathrm{FiO}_{2}\right) \text { at } 2 \text { liters of oxygen per } \\
\text { minute per nasal cannula ( } \mathrm{n}=192)\end{array}$} & $24 \%$ or 0.24 & $38(20,0)$ \\
\hline & $28 \%$ or 0.28 & $119(62,0)$ \\
\hline & $\begin{array}{l}\text { It is not equivalent to a } \\
\text { constant } \mathrm{FiO}_{2}\end{array}$ & $35(18,0)$ \\
\hline \multirow{4}{*}{ Incorrect readings of flowmeters } & \begin{tabular}{|l} 
Image $1(\mathrm{n}=194)$ \\
Image $2(\mathrm{n}=194)$ \\
\end{tabular} & $\begin{array}{r}36(19,0) \\
18(9,0)\end{array}$ \\
\hline & Image $3(n=193)$ & $20(10,0)$ \\
\hline & Image $4(\mathrm{n}=194)$ & $22(11,0)$ \\
\hline & Image $5(\mathrm{n}=195)$ & $36(18,0)$ \\
\hline \multirow{2}{*}{$\begin{array}{l}\text { Identification of inappropriate location of } \\
\text { the sphere in "confounding" image } \\
(\mathrm{n}=194)\end{array}$} & Correct & $104(54,0)$ \\
\hline & Incorrect & $90(46,0)$ \\
\hline
\end{tabular}

Table 3

Answers about complications due to supplemental oxygen use

\begin{tabular}{|c|c|c|}
\hline Question & \multicolumn{2}{|l|}{$\begin{array}{ll}\text { Answer } \mathbf{n}(\%) \\
\end{array}$} \\
\hline \multirow{5}{*}{$\begin{array}{l}\text { Do you know of any complications due to } \\
\text { prolonged use of supplemental oxygen? } \\
\text { Which? } n=156(78 \%)\end{array}$} & Retinopathy of prematurity & $75(48,0)$ \\
\hline & Bronchopulmonary dysplasia & $40(26,0)$ \\
\hline & Epistaxis or erosion of the nasal mucosa & $31(20,0)$ \\
\hline & Difficulty in oxygen weaning & $9(6,0)$ \\
\hline & Oxygen toxicity & $7(5,0)$ \\
\hline \multirow{6}{*}{$\begin{array}{l}\text { Do you know of any complications due to } \\
\text { the use of supplemental oxygen in amounts } \\
\text { greater than necessary? Which? n=134 } \\
(67.3 \%)\end{array}$} & Retinopathy of prematurity & $55(41,0)$ \\
\hline & Volubarotrauma & $21(16,0)$ \\
\hline & Bronchopulmonary dysplasia & $12(9,0)$ \\
\hline & Epistaxis or erosion of the nasal mucosa & $8(6,0)$ \\
\hline & Hyperoxia-hyperoxemia & $7(5,0)$ \\
\hline & Hypercapnia & $5(4,0)$ \\
\hline
\end{tabular}

When inquiring about the equivalence between $\mathrm{FiO}_{2}$ and the number of liters of $\mathrm{O}_{2}$ per minute through nasal cannula, $62 \%$ answered that 2 liters per minute equals $28 \%$ of constant $\mathrm{FiO}_{2}$, followed by very similar results, among 
Evaluation of Knowledge of Oxygen Therapy and Reading of Flowmeter among the Health Workers...

which it was considered that it was equivalent to $24 \%$ of $\mathrm{FiO}_{2}(20 \%)$ and the remaining (18\%) considering that said liters per minute did not equal a constant $\mathrm{FiO}_{2}$ (Table 2).

Additionally, regarding the $\mathrm{SpO}_{2}$ goals according to the age group (young infants, toddlers and children over 2 years), more than $88 \%$ of the respondents considered adequate goals greater than or equal to $91 \%$ at the altitude of Bogotá. When evaluating the knowledge about goals in the neonatal population, the vast majority $(88 \%)$ considered $\mathrm{SpO}_{2}$ goals between $86 \%$ and $95 \%$; 2\%, goals between $81 \%$ and $85 \%$; and $10 \%, \mathrm{SpO}_{2}$ goals equal to or greater than 96\% (Table 4). This last response comes in greater proportion from the nursing team and from medical students.

Table 4

Answers on the Expected Oxygen Saturation Target According to Age Group

\begin{tabular}{|l|r|r|}
\hline \multicolumn{1}{|c|}{ Age group } & Expected oximetry & Answers n (\%) \\
\hline \multirow{3}{*}{$\begin{array}{l}\text { Neonates } \\
\mathrm{n}=195\end{array}$} & $81-85$ & $4(2)$ \\
\cline { 2 - 3 } & $86-95$ & $171(88)$ \\
\cline { 2 - 3 } $\begin{array}{l}\text { Young Infant } \\
\mathrm{n}=198\end{array}$ & $\geq 96$ & $20(10)$ \\
\hline \multirow{2}{*}{$\begin{array}{l}\text { Toddler } \\
\mathrm{n}=198\end{array}$} & $86-90$ & $23(12)$ \\
\hline \multirow{2}{*}{$\begin{array}{l}\text { Older than 2 years } \\
\mathrm{n}=198\end{array}$} & $\geq 91$ & $175(88)$ \\
\cline { 2 - 3 } & $86-90$ & $12(6)$ \\
\hline
\end{tabular}

In reference to the readings of the images of flowmeters, the last image was excluded because it presented extreme results, which were not consistent with the rest of the images. The range of incorrect answers varied between $9 \%$ and 19\%, in general average (Table 2). By subgroups, the students had the lowest frequency of incorrect readings ( $8 \%$ to $14 \%$ ); while Pediatric residents had a higher frequency of incorrect answers (19\% to 44\%). When evaluating the responses of the respiratory therapy group, one respondent answered incorrectly on 3 of the 6 images shown, and a neonatologist $(n=4)$ responded incorrectly on one occasion. The subgroups that most frequently identified the inappropriate location of the sphere in the "confounding" image were the pediatricians ( $68 \%$ of a group of 22 people) and the respiratory therapy team $(67 \%$ of a group of 9 people) (Table 5).

\section{Table 5}

Incorrect Reading of Flowmeters According to the Position Held

\begin{tabular}{|l|r|r|}
\hline \multicolumn{1}{|c|}{ Subgroup } & $\begin{array}{r}\text { Range of incorrect } \\
\text { readings of images } \\
\mathbf{1} \text { to 5 (\%) }\end{array}$ & $\begin{array}{c}\text { Identification of inappropriate location } \\
\text { of the sphere in "confounding" image: } \\
\text { n (\%) }\end{array}$ \\
\hline Medical students & $8-14$ & $45(51,0)$ \\
\hline Nursing team & $4-22$ & $30(55,0)$ \\
\hline Residents & $19-44$ & $8(30,0)$ \\
\hline Pediatricians & $11-17$ & $15(68,0)$ \\
\hline Respiratory therapy team & $12,5^{*}$ & $6(67,0)$ \\
\hline \multicolumn{3}{|c}{ *Corresponds to a single respondent } \\
who answered incorrectly.
\end{tabular}

\section{Discussion}

Oxygen therapy is handled daily in the Department of Pediatrics, and its main objective is to treat hypoxemia and reduce respiratory and cardiac work $(6,7)$. This study shows that there are gaps, failure to update and, sometimes, incorrect knowledge on the use of supplemental $\mathrm{O}_{2}$ and on the reading of the flowmeter within the health personnel evaluated, as well as on the goals of oxygen therapy according to the child's age group and waking state.

A Canadian study made an evaluation of the medical history, the nursing transcript and the administration of oxygen to the patient, which showed that oxygen is not prescribed or administered with the same rigor as other drugs such as antibiotics (16). In the present study, 99\% of the participants considered oxygen as a drug, $91 \%$, indicated that $\mathrm{O}_{2}$ is often prescribed with its dose in the medical history, and $84 \%$ answered that the $\mathrm{SpO}_{2}$ goal is stated in the medical history

More than three quarters of the participants know at least one complication due to prolonged use of $\mathrm{O}_{2}$ or in amounts greater than necessary; however, $10 \%$ answered that high $\mathrm{SpO}_{2}$ goals should be achieved for the neonatal population, which represents the population group most vulnerable to adverse effects due to inappropriate use of supplemental $\mathrm{O}_{2}$. In $22 \%$ of the respondents, there was an erroneous knowledge regarding the variation of the saturation according to the child's waking 
state. An updated concept in oxygen therapy is that there is no equivalence between the number of liters administered and a constant $\mathrm{FiO}_{2}$, since the patient's physiological variables and the differences between the $\mathrm{O}_{2}$ supply devices influence this comparison, and it is not possible to ensure a constant $\mathrm{FiO}_{2}$; only $18 \%$ of the participants in the survey answered the question correctly. Regarding the reading of flowmeters, between $9 \%$ and 19\% of the responses for the different images were incorrect, with the subgroup of residents having the highest frequency of erroneous readings. The pediatricians and the respiratory therapy team were the groups that most frequently identified the inadequate location of the flowmeter sphere in the "confounding" image, which could be related to their knowledge and years of experience.

There are some clinical studies with a good sample size that evaluate the normal saturation values in healthy children at different altitudes above sea level, according to the state of consciousness. Annex 2 summarizes the saturation values found in studies conducted at different altitudes above sea level, according to the age group up to 5 years $(3,17,18,19,20,21)$.

One strength of the study is that we did not find evidence in the literature of similar studies that evaluate the correct reading of the flowmeter by health personnel. In addition, it allows to determine areas of knowledge about oxygen therapy that should be reinforced. The largest group of students was taken on one same occasion, simultaneously and individually, and their answers were the most correct regarding flowmeter reading, which suggests that they have a better training.

Regarding the limitations, we must assume the possibility of a "nonresponder" bias, since the survey was totally voluntary; additionally, it was delivered printed, so this could have caused the incomplete filling of the survey in some participants. We had a small sample size in the population of neonatologists and in the respiratory therapy team. The nursing and respiratory therapy staff surveyed corresponds to the group of the day shift, which could indicate that the results for the night shift staff could vary. The surveys were not answered on consecutive days; nevertheless, it was carried out for seven days to try to reduce the risk of contamination. Answers were lost in different questions of the survey because the participant did not complete them.

Although $\mathrm{O}_{2}$ is used daily, there are people from the Department of Pediatrics with incorrect knowledge regarding its proper management. Education on the correct way to read the flowmeter should be encouraged, and it is necessary to reinforce updated concepts on oxygen therapy in the health personnel of the Department of Pediatrics of HUSI, such as adverse effects, $\mathrm{SpO}_{2}$ goals by age group according to the altitude above sea level and the state of consciousness. Periodic educational campaigns are being implemented to update the knowledge about this valuable drug and to unify the language that must be handled in the hospital setting within the personnel responsible for oxygen administration.

\section{Conclusions}

This study presents a general overview of the knowledge of oxygen therapy in the health personnel who usually administer this drug. A considerable percentage of the respondents had errors regarding saturation according to the waking state $(22 \%)$ and the reading of flowmeters (up to $19 \%$ were incorrect); in addition, almost a quarter of respondents do not know the complications of prolonged $\mathrm{O}_{2}$ use. One third of the respondents is unaware of the adverse effects of administering a $\mathrm{FiO}_{2}$ higher than necessary, and $10 \%$ of respondents have errors about saturation goals for the neonatal population. This allows to emphasize the need to deepen on this topic, to make periodic educational campaigns and to recommend carrying out similar studies in different institutions of the country to ensure the unification of criteria and knowledge in the Pediatric units. 


\section{References}

1. Sola A. Oxygen saturation in the newborn and the importance of avoiding hyperoxia-induced damage. Neoreviews. 2015;16(7):393-405.

2. Mellingen $\mathrm{H}$, Langeland AJ, Graue M. Oxygen therapy to children in hospitals. Sykepl Forsk. 2016;11(2):126-33.

3. Lozano JM, Duque OR, Buitrago T, Behaine S. Pulse oximetry reference values at high altitude. Arch Dis Child. 1992;67 (11):299-301.

4. Cairo J. Administering medical gases: regulators, flowmeters, and controlling devices. In: Mosby's respiratory care equipment. 9th ed. Missouri: Elsevier; 2014. p. 37-47.

5. Davidson J, Gazzeta C, Torres LC, Jardim JR, Nascimento O. Precision and accuracy of oxygen flow meters used at hospital settings. Respir Care. 2012;57(7):1071-5.

6. Posada Díaz A, Parra Cardeño W, editores. Guía de práctica clínica: oxigenoterapia [Internet]. Medellin: Asociación Colombiana de Neumología Pediátrica; 2010. Disponible en. https://issuu.com/acnp/ docs/oxigenoterapia1

7. Comité Nacional de Neumología. Guías para el manejo de la oxigenoterapia domiciliaria en pediatría. Parte 1: Generalidades, indicaciones y monitoreo. Arch Argent Pediatr. 2013;111(5):448-54.

8. World Health Organization. Oxygen therapy for children: A manual for healh workers [Internet]. Geneva: WHO; 2016. Available from: http://apps.who.int/iris/bitstream /10665/204584/1/9789241549554_eng .pdf.

9. Cooper N, Forrest K, Cramp P. Oxygen therapy. In: Essential guide to acute care. 2a ed. Philadelphia: John Wiley \& Sons; 2008. p. 14-35.

10. Duprez F, Barile M, Bonus T, Cuvelier G, Ollieuz S, Mashayekhi $S$, et al. Accuracy of medical oxygen flowmeters: A multicentric field study. Health (Irvine Calif). 2014;6(15):1978-83.

11. Walsh BK, Smallwood CD. Pediatric oxygen therapy: A review and update. Respir Care [Internet]. 2017;62(6):645-61. Available from: http://rc.rcjournal.com /lookup/doi/10.4187/respcare.05245

12. Torres Y, Osorio L, Ramos N. Medición de los valores de oximetría de pulso durante sueño, vigilia y succión en neonatos sanos en Bogotá (2640 metros de altura sobre el nivel del mar). Av Pediátricos. 1999;1:2-8.

13. Hay WW, Bell EF. Oxygen therapy, oxygen toxicity, and the STOP-ROP Trial. Pediatrics. 2000;105:424.

14. Askie L, Henderson-Smart D, Irwig L, Simpson J. Oxygen-saturation targets in extremely preterm infants. $\mathrm{N}$ Engl J Med. 2013;368(20):1949-50.

15. Bancalari MA. Estrategias de prevención y tratamiento en displasia broncopulmonar. Rev Chil Pediatr. 2009;80 (4):309-22.

16. Small D, Duha A, Wieskopf B, Dajczman E, Laporta D, Kreisman H, et al. Uses and misuses of oxygen in hospitalized patients. Am J Med. 1992;92(6):591-5.

17. Ucrós S, Granados C, Parejo K, Guillén F, Ortega F, Restrepo S, et al. Saturación de oxígeno, respiración periódica y apnea durante el sueño en lactantes de 1 a 4 meses a 2560 metros de altura. Arch Argent Pediatr. 2015;113(4):341-4.

18. Duenas-Meza E, Bazurto-Zapata MA, Gozal D, González-García M, Durán-Cantolla J, Torres-Duque 
CA. Overnight polysomnographic characteristics and oxygen saturation of healthy infants, 1 to 18 months of age, born and residing at high altitude (2,640 meters). Chest. 2015;148(1):120-7.

19. Ucrós S, Granados C, Parejo K, Ortegad F, Guillén F, Restrepo S, et al. Saturación de oxígeno, respiración periódica y apnea durante el sueño en lactantes de 1 a 4 meses a 3200 metros de altura. Arch Argent Pediatr. 2017;115(1):50-7.

20. Thilo EE, Park-Moore B, Berman ER, Carson BS. Oxygen saturation by pulse oximetry in healthy infants at an altitude of $1610 \mathrm{~m}(5280 \mathrm{ft})$ : What is normal? Am J Dis Child. 1991;145(10):1137-40.

21. Escamilla JM, Morales J, Romero D, Caraballo A, Gil I. Valores de referencia de la saturación arterial de oxígeno mediante oximetría de pulso en niños y en adolescentes sanos entre 2 y 17 años en Cartagena. Rev Pediatr. 2010;43(2):92-9.

\section{Annex 1}

\section{Examples of photographs of flowmeters of the Hospital Universitario San Ignacio used in the Survey}

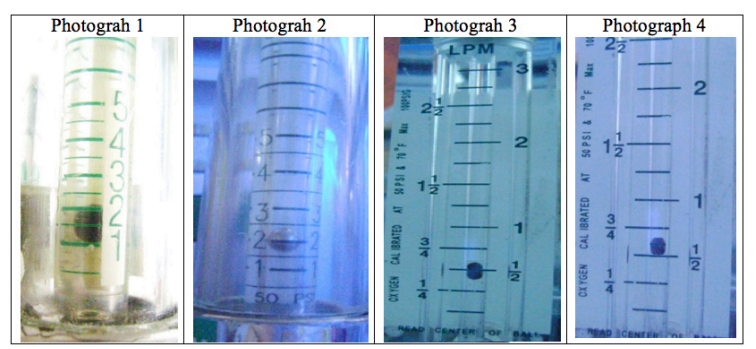

Photograh 1: Represents flow of 1.5 liters per minute (L/min). Photograh 2: Represents flow of $2 \mathrm{~L} / \mathrm{min}$. Photograh 3: Represents flow of $0.5 \mathrm{~L} / \mathrm{min}$. Photograh 4 or "confounding" photograh: Does not indicate a specific $\mathrm{O}_{2}$ flow.

\section{Annex 2}

Saturation values in healthy children at different altitudes above sea level according to the state of consciousness. Obtained from literature review

\begin{tabular}{|c|c|c|c|c|c|c|}
\hline & \multicolumn{2}{|c|}{ Age } & $\begin{array}{c}\text { Sleep } \\
\text { Me (P5-95) }\end{array}$ & $\begin{array}{c}\text { Wake } \\
\text { Me (P5-95) }\end{array}$ & $\begin{array}{c}\text { Altitude } \\
\text { above sea } \\
\text { level (masl) }\end{array}$ & Reference \\
\hline \multirow{3}{*}{ 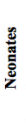 } & \multirow{2}{*}{$0-30$ days } & $\mathrm{n}=39$ & - & 92.6 & \multirow{3}{*}{2.640} & Lozano, 1992 (3) \\
\hline & & $\mathrm{n}=300$ & $\begin{array}{c}92.5 \\
(84.6-98.5)\end{array}$ & $\begin{array}{c}95.0 \\
(90.5-98.8)\end{array}$ & & Torres, 1999 (12) \\
\hline & $0-45$ days & $n=106$ ) & $\begin{array}{c}92.5 \\
(87-96)\end{array}$ & $\begin{array}{c}92.5 \\
(88-96)\end{array}$ & & Dueñas-Mesa, 2015 (18) \\
\hline \multirow{9}{*}{ 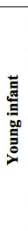 } & \multirow{2}{*}{\multicolumn{2}{|c|}{$\begin{array}{l}1 \text { month }(\mathrm{n}=100) \\
1-3 \text { months }(\mathrm{n}=35)\end{array}$}} & $92.3 \pm 0.244$ & $93.4 \pm 0.2 \bullet$ & 1,610 & Thilo, 1991 (20) \\
\hline & & & & 93.40 .26 & $\begin{array}{l}\frac{1,010}{2,640} \\
-\end{array}$ & Lozano, $1992(3)$ \\
\hline & \multirow{3}{*}{$\begin{array}{l}3 \text { months } \\
1-4 \\
\text { months }\end{array}$} & $=63)$ & $92.2 \pm 0.4 \bullet \bullet$ & $93.5 \pm 0.3 \bullet \bullet$ & 1,610 & Thilo, 1991 (20) \\
\hline & & $\mathrm{n}=35$ & $92(86-94)$ & 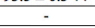 & 2,510 & Ucrós, $2015(17)$ \\
\hline & & $\mathrm{n}=18$ & $87(66-91)$ & $89(76-91)$ & 3,200 & Ucrós, 2017 (19) \\
\hline & \multirow{2}{*}{\multicolumn{2}{|c|}{ 3-4 months ( $\mathrm{n}=89$ ) }} & $93(86-96)$ & $93(88-96)$ & \multirow{7}{*}{2,640} & Dueñas-Mesa, 2015 (18) \\
\hline & & & - & 93.54 & & Lozano, 1992 (3) \\
\hline & \multicolumn{2}{|c|}{ 6-7 months } & $94(90-96)$ & 94 (91-97) & & Dueñas-Mesa, 2015 (18) \\
\hline & \multicolumn{2}{|c|}{$\begin{array}{l}7-12 \text { months } \\
(\mathrm{n}=23)\end{array}$} & - & $93.4 \bullet$ & & Lozano, 1992 (3) \\
\hline \multirow{3}{*}{ 密 } & \multicolumn{2}{|c|}{$\begin{array}{l}(\mathrm{n}=23) \\
10-18 \text { months }(\mathrm{n}=25)\end{array}$} & $94(91-96)$ & $95(91-96)$ & & Dueñas-Mesa, 2015,(18) \\
\hline & \multirow{2}{*}{\multicolumn{2}{|c|}{$\begin{array}{l}13-18 \text { months }(\mathrm{n}=38) \\
19-24 \text { months }(\mathrm{n}=30)\end{array}$}} & - & $93.7+$ & & Lozano, 1992 (3) \\
\hline & & & - & $93 \bullet$ & & \multirow{3}{*}{ Escamilla, 2010 (21) } \\
\hline \multirow{2}{*}{$\underset{\pi}{\Delta}$} & \multicolumn{2}{|l|}{$(\mathrm{n}=48)$} & - & 97.94 & \multirow[b]{2}{*}{2} & \\
\hline & \multicolumn{2}{|c|}{$\begin{array}{l}10-17 \text { years } \\
(\mathrm{n}=134)\end{array}$} & - & 98 • & & \\
\hline
\end{tabular}

$>2$ yr: Older than 2 years; Me (P5-95):

Median (Percentile 5 - Percentile 95); masl:

Meters above sea level; $\bullet$ : The data are

presented in Average; $\bullet \bullet:$ The data are presented in Average \pm Standard deviation. 